\title{
Naloxone reduces fluid consumption in water-deprived and nondeprived rats
}

\author{
JUNE M. STAPLETON, NANCY L. OSTROWSKI, VICKI J. MERRIMAN, \\ MARCIA D. LIND, and LARRY D. REID \\ Rensselaer Polytechnic Institute, Troy, New York 12181
}

\begin{abstract}
Naloxone hydrochloride, in doses of .5 to $10 \mathrm{mg} / \mathrm{kg}$ intraperitoneally, reduced water consumption by rats fluid deprived for $24 \mathrm{~h}$. Administered intracerebroventricularly, 100 micrograms of naloxone produced similar effects while doses of 50 micrograms or less had no effect. Naloxone $(10 \mathrm{mg} / \mathrm{kg})$ also reduced consumption of a palatable solution (10\% sucrose, weight/volume) by nondeprived rats. Morphine sulfate $(.5$ to $2 \mathrm{mg} / \mathrm{kg}$ ) failed to increase consumption.
\end{abstract}

For some time after the discovery of its opioid antagonist properties, naloxone was thought to be essentially inert in biological systems in the absence of a narcotic agonist (Jaffe \& Martin, 1975). It is now apparent, however, that naloxone does have some effects when administered to opioid-naive subjects (Belluzzi \& Stein, 1977; Maickel, Braude, \& Zabik, 1977). It has been suggested that naloxone has its effects by blocking the endogenous opioids, which may exist as tonic modulators or be present only under specific circumstances (Goldstein, 1978).

\section{EXPERIMENT 1}

Holtzman (1974) demonstrated that naloxone modified eating, and Maickel et al. (1977) have reported that a variety of opioid agonists and antagonists modify drinking in rats. Experiment 1 tested the effects of naloxone and morphine on drinking in water-deprived rats.

\section{Method}

Subjects and Apparatus. The subjects were nine, male, albino rats (Taconic Farms, Sprague-Dawley derived) weighing 300 to $430 \mathrm{~g}$ at the start of procedures. The rats had previously served as placebo control subjects in a study of conditioned taste aversions (Stapleton, Lind, Merriman, Bozarth, \& Reid, in press). Consequently, they were well trained to take a daily ration of water during a 15 -min opportunity to drink but had no history of drug administration. Subjects were individually housed with free access to food and access to water as specified. Water bottles equipped with ball-point sipping tubes were weighed to an accuracy of $.5 \mathrm{~g}$ to measure fluid consumption.

Procedure. Rats were maintained on a fluid-deprivation schedule. Water was presented for $15 \mathrm{~min} /$ day. Fifteen minutes prior to the daily water presentation, each rat received a subcutaneous (sc) injection, $1 \mathrm{ml} / \mathrm{kg}$. The procedures spanned 18 days, during which the amount drunk during $15 \mathrm{~min}$ was measured daily. On certain test days, half the rats received placebo injections and half received drug injections. All rats were tested twice under naloxone hydrochloride $(10 \mathrm{mg} / \mathrm{kg})$,

This work was supported by Grant DA02044 from the National Institute on Drug Abuse. Naloxone hydrochloride was provided courtesy of Endo Laboratories. twice under morphine sulfate $(.5 \mathrm{mg} / \mathrm{kg})$, and once under morphine sulfate $(.25 \mathrm{mg} / \mathrm{kg})$. On other days, all rats received placebo injections of physiological saline, the carrier of naloxone and morphine.

\section{Results and Discussion}

Scores of daily fluid consumption were submitted to a 1 by 18 analysis of variance (ANOVA) having repeated measures with factors of 1 group and 18 treatments. It yielded $F(17,136)=3.91(p<.001)$ for the factor of treatments. Figure 1 summarizes the consumption on test days only, averaged across all tests of each drug and dose. On a t test for correlated measures, the placebo-naloxone comparison shows a statistically significant difference $[t(8)=3.82, \mathrm{p}<.01]$, while the scores for morphine sulfate doses of $.5 \mathrm{mg} / \mathrm{kg}$ and $.25 \mathrm{mg} / \mathrm{kg}$ were not significantly different from placebo scores $[\operatorname{ts}(8)=.75,1.02$, respectively, ps $>.25]$. When rats were under naloxone they started drinking as soon as the water was made available but stopped

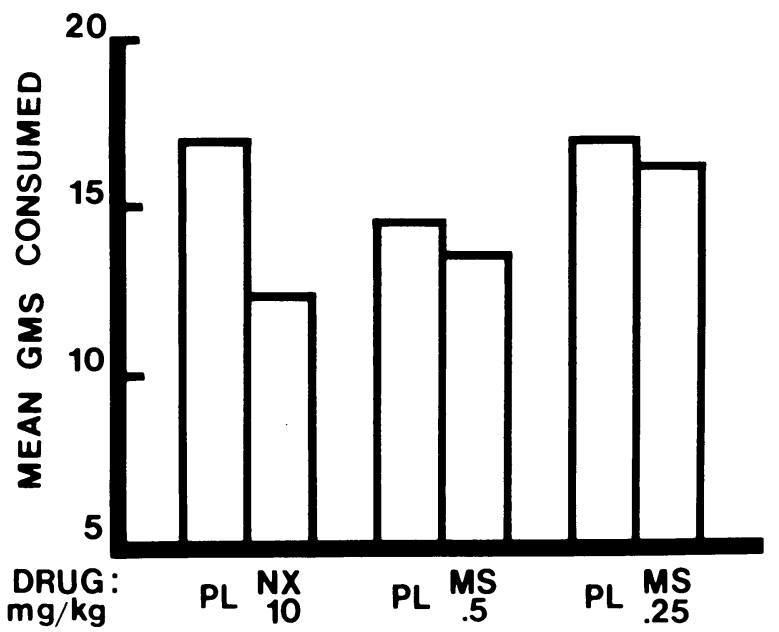

Figure 1. Mean grams of water consumed during each 15-min test. $P L=$ placebo, physiological saline, $1 \mathrm{ml} / \mathrm{kg}$; $\mathrm{NX}, 10=$ naloxone hydrochloride, $10 \mathrm{mg} / \mathrm{kg} ; \mathrm{MS}, .5=$ morphine sulfate, $.5 \mathrm{mg} / \mathrm{kg}$; MS, $.25=$ morphine sulfate, $.25 \mathrm{mg} / \mathrm{kg}$. Injections were given subcutaneously $15 \mathrm{~min}$ before the test. 
drinking sooner than when they were under placebo.

To verify that the naloxone effect was not specific to rats trained to drink for $15 \mathrm{~min} /$ day, we also tested 18 experimentally naive, adult, male, albino rats (Taconic Farms). They were water deprived for $24 \mathrm{~h}$, injected with naloxone hydrochloride $(10 \mathrm{mg} / \mathrm{kg}, \mathrm{sc})$ or physiological saline in equivalent volume $(1 \mathrm{ml} / \mathrm{kg})$ and $15 \mathrm{~min}$ later were presented with water for $15 \mathrm{~min}$. The naloxone group drank significantly less than the placebo group $[\mathrm{t}(16)=4.97, \mathrm{p}<.001]$, indicating that the effect appears even in animals not previously trained to drink on a schedule.

The lack of effect produced by morphine injections was surprising given the previous report by Maickel et al. (1977) of morphine-induced increases in drinking. Possible reasons for the discrepancy between our results and those of Maickel et al. could be the rats' prior exposure to naloxone or other procedural differences including the duration of testing (15 vs. $60 \mathrm{~min}$ ) and the presence or absence of food during the test. To explore the possibilities, 20 experimentally naive, adult, male, albino rats (Taconic Farms) were maintained on a fluid-deprivation schedule and tested under doses of morphine ranging from 0 to $2 \mathrm{mg} / \mathrm{kg}$ with these parameters (duration of testing, with and without food available, drug history) systematically varied. Morphine produced no statistically significant effect on drinking under any of the conditions tested. The possibility that the difference might be due to differences in strain of rats used (Sprague-Dawley vs. Wistar) remains to be considered. Data of Rhines and Ford (1977) suggest that these two strains do show differential reactivity to some effects of morphine.

\section{EXPERIMENT 2}

Experiment 2 addressed the question of whether the naloxone-induced decrease in drinking might be a central nervous system effect or a peripheral effect. Experiment 1 used a fairly large dose of naloxone, sc. It was thought that if the intracerebroventricular (ICV) dose required to produce this effect were much smaller than the dose required systemically, this would support the idea that the naloxone effect is a central effect.

\section{Method}

Subjects and Apparatus. The subjects were 36, adult, male, albino rats weighing $350-525 \mathrm{~g}$ at the start of procedures. All rats had served as subjects in a previous study (Stapleton et al., Note 1). Each had a 23-gauge guide cannula implanted in the lateral ventricle (coordinates: $.9 \mathrm{~mm}$ anterior and $1.5 \mathrm{~mm}$ lateral to bregma, $3.5 \mathrm{~mm}$ below the surface of the skull, with bregma and lambda in the same horizontal plane). Subjects were matched according to previous opioid history and assigned to four groups $(n=9)$. All rats were individually housed with free access to food and access to water as specified.

Infusions were performed with a 10-microliter syringe (Hamilton 701) equipped with a 30 -gauge injection cannula that extended $1 \mathrm{~mm}$ past the tip of the guide cannula during infusions.
Glass water bottles equipped with ball-point sipping tubes were weighed to an accuracy of $.5 \mathrm{~g}$ to measure fluid consumption.

Procedure. Rats were maintained on a fluid-deprivation schedule. Water was presented for $15 \mathrm{~min} /$ day. On Day 1, all rats received an ICV infusion of naloxone hydrochloride $(0,10$, 50 , or 100 micrograms) in physiological saline, 5 microliter volume, $15 \mathrm{~min}$ before the daily water presentation. On Day 3, half the rats received naloxone hydrochloride $(1 \mathrm{mg} / \mathrm{kg}, \mathrm{sc})$, the others received physiological saline in equivalent volume $(1 \mathrm{ml} / \mathrm{kg}, \mathrm{sc})$. On Day 5, the groups' treatments were reversed and one half was given placebo and the other half naloxone hydrochloride $(.5 \mathrm{mg} / \mathrm{kg}, \mathrm{sc})$. On Days 2,4 , and 6 , there were no injections. On Day 7, 12 randomly selected rats were retested with naloxone hydrochloride ( 0 or 50 micrograms) given ICV immediately before the test.

\section{Results}

Mean water consumptions following ICV infusions (Day 1) are shown in Figure 2. A one-way ANOVA on the scores from which this figure is derived yielded $F(3,23)=3.03(p<.05)$. Further analyses lead to the conclusion that only the 100 -microgram dose reduced consumption reliably, compared to the placebo group $[\mathrm{t}(16)=2.20, \mathrm{p}<.05]$.

On Day 3, the group receiving naloxone $(1 \mathrm{mg} / \mathrm{kg}, \mathrm{sc})$ consumed significantly less than the placebo group $[\mathrm{t}(34)=2.90, \mathrm{p}<.01]$, and on Day 5 , the group receiving naloxone $(.5 \mathrm{mg} / \mathrm{kg}$, sc) also drank less than the placebo group $[t(34)=3.26, p<.01]$. The scores of the two groups were not reliably different from each other on no-injection days $[\operatorname{ts}(34)=.70, .81,1.94$, all ps $>.05]$. On Day 7, the scores of consumption of the group given 50 micrograms were not reliably different from those of the placebo group $[t(10)=1.25, p>.20]$.

To summarize, an ICV dose of 50 micrograms or less produced no reliable decrease in water consumption; 100 micrograms ICV did produce a decrease. Administered systemically, doses as small as $.5 \mathrm{mg} / \mathrm{kg}$ or about $250 \mathrm{micrograms} / \mathrm{rat}$ produced a reliable decrease. Since quite a small systemic dose or a moderately large ICV

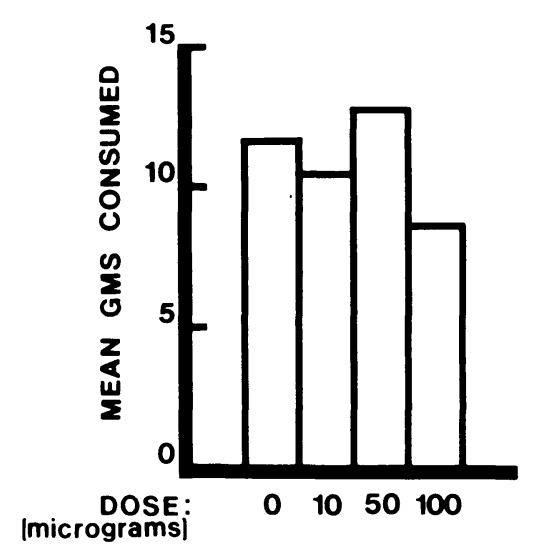

Figure 2. Mean grams of water consumed by four groups of rats during a 15-min test following intracerebroventricular infusion of naxolone hydrochloride $(0,10,50$, or 100 microgram) in physiological saline, 5 microliter volume. 
dose seem to have similar consequences, the possibility that naloxone may be acting through some systemic mechanism rather than through direct brain action remains open.

\section{EXPERIMENT 3}

In previous tests of the effects of naloxone on appetitive behavior (Holtzman, 1974; Maickel et al., 1977), rats have been deprived of water or food. This experiment tested whether naloxone would reduce consumption of a palatable solution not required to meet nutritional deficits.

\section{Method}

The subjects were 20 , experimentally naive, adult, male, albino rats (Taconic Farms) weighing 300 to $450 \mathrm{~g}$ at the start of procedures. Subjects were individually housed with free access to food and water, except as specified below. Glass water bottles equipped with ball-point sipping tubes were weighed to an accuracy of $.5 \mathrm{~g}$ to measure fluid consumption.

Rats were presented with a $10 \%$ sucrose solution (weight/ volume) in tap water for $1 \mathrm{~h} /$ day. During this hour, the regular water bottles were removed and the sucrose solution was substituted in the home cage. After 3 days to habituate to this regimen, rats were given daily injections $15 \mathrm{~min}$ before the opportunity to consume sucrose solution. On Days 1 and 3, all rats received physiological saline $(1 \mathrm{ml} / \mathrm{kg}$, sc); on Day 2 , one half received naloxone hydrochloride $(10 \mathrm{mg} / \mathrm{kg}, \mathrm{sc})$ and the other half received physiological saline $(1 \mathrm{ml} / \mathrm{kg}, \mathrm{sc})$, the carrier of naloxone.

\section{Results}

On Day 2, the placebo group consumed a mean of $18.6 \mathrm{~g}$, while the naloxone group consumed only $5.9 \mathrm{~g}$, a statistically significant difference $[\mathrm{t}(18)=8.04$, $\mathrm{p}<.001]$. The two groups were not reliably different on Days 1 and $3[\operatorname{ts}(18)=.81,1.75$, respectively, ps $>.05]$. These results, plus a replication using a slightly different procedure but yielding similar results, provide convincing evidence that naloxone reduces this type of appetitive behavior.

\section{GENERAL DISCUSSION}

These experiments produced the following results: (1) Naloxone produces a small, consistent decrease in water consumption of deprived rats across a variety of conditions of testing and drug administration. (2) A small, systemic dose $(.5 \mathrm{mg} / \mathrm{kg})$ or a moderately large ICV dose (100 micrograms/ infusion) is sufficient to produce the effect of reduced consumption of water. (3) Naloxone produces a large decrease in consumption of a palatable solution in nondeprived rats.

A hypothesis that might explain these findings is that the naloxone blocking of the activity of endogenous opioids modifies appetitive processes. Explanations along these lines could also account for previously reported naloxone suppression of press rates for intracranial stimulation (Belluzzi \& Stein, 1977). On the other hand, the lack of a morphine effect in these experiments (i.e., a failure to find a bipolar effect) leaves open the possibility that decreases in consumption are due to a nonspecific effect such as nausea or general malaise following naloxone administration. Previous studies indicate that naloxone can produce a conditioned taste aversion (LeBlanc \& Cappell, 1975; Stolerman, Pilcher, \& D'Mello, 1978; Van der Kooy \& Phillips, 1977), and there have been reports of nausea and dysphoria in humans given narcotic antagonists (Gitlin \& Rosenblatt, 1978). It is possible that decreases in feeding, drinking, and self-stimulation all stem from a mild, nonspecific illness produced by naloxone, and this hypothesis cannot be ruled out on the basis of the data presently available. Yet, it is clear that naloxone does modify appetitive behavior, and these effects may be important clues to the functioning of the endorphins or may be an intrusive variable in studies searching for the role of endorphins in the regulation of behavior.

\section{REFERENCES}

Belluzzi, J. D., \& Stein, L. Enkephàlin may mediate euphoria and drive-reduction reward. Nature, 1977, 266, 556-558.

Gitlin, M., \& Rosenblatt, M. Possible withdrawal from endogenous opiates in schizophrenia. American Journal of Psychiatry, 1978, 135, 377-378.

Goldstein, A. Opiate receptors and opioid peptides: A ten-year overview. In M. A. Lipton, A. DiMascio, \& K. F. Killam (Eds.), Psychopharmacology: A generation of progress. New York: Raven Press, 1978.

Holtzman, S. G. Behavioral effects of separate and combined administration of naloxone and d-amphetamine. The Journal of Pharmacology and Experimental Therapeutics, 1974, 189, 51-60.

JAFFE, J. H., \& MARTIN, W. R. Narcotic analgesics and antagonists. In L. S. Goodman \& A. Gilman (Eds.), The pharmacological basis of therapeutics. New York: Macmillan, 1975.

LeBlanc, A. E., \& Cappell, H. Antagonism of morphineinduced aversive conditioning by naloxone. Pharmacology, Biochemistry and Behavior, 1975, 3, 185-188.

Maickel, R. P., Braude, M. C., \& Zabik, J. E. The effects of various narcotic agonists and antagonists on deprivationinduced fluid consumption. Neuropharmacology, 1977, 16, 861-866.

Rhines, R. K., \& Ford, D. H. The effect of naloxone and morphine on $3 \mathrm{H}$-1-lysine in vivo incorporation into various neurons separated from fixed rat brain preparations by ultrasonifications: A comparison of morphine effects between Wistar and Sprague-Dawley rats. Acta Neurologica Scandinavica, 1977, 56, 445-460.

Stapleton, J. M., Lind, M. D., Merriman, V. J., Bozarth, M. A., \& REID, L. D. Affective consequences and subsequent effects on morphine self-administration of $\mathrm{d}$-ala ${ }^{2}$-methionine enkephalin. Physiological Psychology, in press.

Stolerman, I. P., Pilcher, C. W. T., \& D'Mello, G. D. Stereospecific aversive property of narcotic antagonists in morphine-free rats. Life Sciences, 1978, 22, 1755-1762.

VAN DER Kooy, D., \& PhILIPs, A. G. Temporal analysis of naloxone attenuation of morphine-induced taste aversion. Pharmacology, Biochemistry and Behavior, 1977, 6, 637-641.

(Received for publication January 16, 1979.) 